\title{
Evaluation methods and objectives for neuromuscular and hemodynamic responses subsequent to different rest intervals in resistance training: a systematic review
}

\author{
Jurandir Baptista da Silva ${ }^{1,2}$, Leandro de Lima e Silva ${ }^{1,2}$, Rodolfo Alkmim Moreira Nunes ${ }^{1,2}$, Gustavo Casimiro Lopes ${ }^{1,2}$, \\ Danielli Braga de Mello ${ }^{3}$, Vicente Pinheiro Lima ${ }^{1,2,4}$, Rodrigo Gomes de Souza Vale \\ 'Universidade do Estado do Rio de Janeiro (PPGCEE/UERJ). Rio de Janeiro. Brasil. 2Laboratório do Exercício e Esporte (LABEES/UERJ). Rio de Janeiro. Brasil. ${ }^{3}$ Escola de Educação Física \\ do Exército (EsEFEx). Rio de Janeiro. Brasil. ${ }^{4}$ Grupo de Pesquisa em Biodinâmica e Desempenho, Exercício e Saúde (BIODESANUCB). Rio de Janeiro. Brasil. ${ }^{5}$ Laboratório de Fisiologia \\ do Exercício. Universidade Estácio de Sá. Cabo Frio. Rio de Janeiro. Brasil.
}

doi: 10.18176/archmeddeporte.00041

Recibido: $21 / 03 / 2020$

Aceptado: 17/02/2021

Key words:

Resistance training. Muscle stress. Rest. Recovery.

Palabras clave: Entrenamiento de resistencia. Estrés muscular. Descanso. Recuperación.

\section{Summary}

Introduction: The training routine planned, and performed correctly results in exercises that, systematically organized, influence the levels of strength, and muscle hypertrophy. However, the magnitudes of these gains vary considerably. To optimize these gains, it is important to underst, and the interaction between training variables such as external load, volume, number of exercises, number of repetitions, duration of repetitions, the order of exercises, number of series, recovery interval between series, and the exercises, as well as the time under tension. The influence of the recovery interval on the response following exercise on neuromuscular components is very important. However, different objectives, and instruments are used to evaluate these responses.

Objective: The purpose of this study is to conduct a systematic review of the assessment methods, and objectives for responses after different recovery intervals in strength training. METHODS: The present study is characterized by a systematic review study. Articles found in the following databases were considered for the systematic review: Scopus, PubMed / MEDLINE, Web of Science, Cochrane Library. The following descriptors, and their respective synonyms according to the terms MeSH were used in the databases, both singular, and plural: "Resistance Training", "Rest Interval", and "Bech Press". As filters were used: a) species (humans), and type of study (original).

Results: Seven studies were analyzed that met the established criteria.

Conclusion: The studies presented have verified the influence of different recovery intervals on muscle, and hemodynamic responses. Evaluating image measurements such as ultrasound, and resonance, blood measurements such as GH, Testosterone, IGF-1, and Lactate, number of repetitions for performance, and fatigue, as well as heart rate, and blood pressure.

Métodos de evaluación y objetivos para las respuestas neuromusculares y hemodinámicas posteriores a diferentes intervalos de descanso en el entrenamiento de resistencia: una revisión sistemática

\section{Resumen}

Introducción: La rutina de entrenamiento planificada y realizada correctamente da como resultado ejercicios que, organizados sistemáticamente, influyen en los niveles de fuerza e hipertrofia muscular. Sin embargo, las magnitudes de estas ganancias varían considerablemente. Para optimizar estas ganancias, es importante comprender la interacción entre las variables de entrenamiento como la carga externa, el volumen, el número de ejercicios, el número de repeticiones, la duración de las repeticiones, el orden de los ejercicios, el número de series, el intervalo de recuperación entre series y los ejercicios, así como el tiempo bajo tensión. La influencia del intervalo de recuperación en la respuesta después del ejercicio en los componentes neuromusculares es muy importante. Sin embargo, se utilizan diferentes objetivos e instrumentos para evaluar estas respuestas. Objetivo: El propósito de este estudio es realizar una revisión sistemática de los métodos y objetivos de evaluación para las respuestas posteriores a los diferentes intervalos de recuperación en el entrenamiento de fuerza. MÉTODOS: El presente estudio se caracteriza por un estudio de revisión sistemática. Los artículos encontrados en las siguientes bases de datos se consideraron para la revisión sistemática: Scopus, PubMed / MEDLINE, Web of Science, Cochrane Library. Los siguientes descriptores y sus respectivos sinónimos según los términos MeSH se utilizaron en las bases de datos, tanto en singular como en plural: "Entrenamiento de resistencia","Intervalo de descanso" y"Bench Press". Como filtros se utilizaron: a) especies (humanos) y tipo de estudio (original).

Resultados: Se analizaron siete estudios que cumplieron con los criterios establecidos.

Conclusión: Los estudios presentados han verificado la influencia de diferentes intervalos de recuperación en las respuestas musculares y hemodinámicas. Evaluación de mediciones de imagen como ultrasonido y resonancia, mediciones de sangre como GH, testosterona, IGF-1 y lactato, número de repeticiones para el rendimiento y la fatiga, así como la frecuencia cardíaca y la presión arterial. 


\section{Introduction}

Resistance training has usually applied to overload the musculoskeletal system?'. This type of training is established as an effective method for the development of musculoskeletal fitness, and is recommended to improve health, and performance ${ }^{2}$. The planned, and properly executed training routine results in exercises that, systematically organized, influence muscle strength, and hypertrophy levels ${ }^{3}$. However, the magnitudes of these gains vary considerably 4 .

To improve these gains, it is important to underst, and the interaction between training variables such as external load, volume, number of exercises, number of repetitions, repetition duration, exercise order, number of series, the interval of recovery between series, and exercises, as well as tense time ${ }^{5}$. Thus, the understanding, anding of definitions, principles, and methods for the prescription of a strength training routine is necessary for a safe, and efficient prescription ${ }^{6}$.

An important variable explored during training is the rest interval time (RI) between the series. The RI can be defined as the recovery period between exercise series during a training session. Intervals can be set in short (up to 1 minute), medium (1 to 3 minutes), and long (more than 3 minutes) $)^{7}$. Through it, one can manipulate the stress exerted in the musculature by the adequacy or maintenance of the intensity, and volume of training.

According to the data included in a recent systematic review ${ }^{8}$, when the goal of training is strength gains, long RI should be prioritized thus allowing the maintenance of the number of repetitions. However, to optimize muscle hypertrophy gains, short Rl is suggested to promote increased metabolic stress, and possible anabolism?.

In addition to the muscle system, the prescription of strength training exercises also influences the responses of other systems of the human body ${ }^{10}$. Different RI between series promotes different influences on cardiovascular, endocrine, and neural systems ${ }^{11}$. The variation in heart rate, blood pressure, the varying curves of specific hormone, and enzyme levels, and the behavior of the spread of action potential are some examples.

Some instruments, and methods are used to evaluate these parameters. Blood collections, imaging tests such as thermography, and ultrasound, electromyography, dual Energy radiological absorptiometry (DXA) are examples of specific evaluations on biological response. Moreover, the maintenance of the number of repetitions performed also represents an important response to the exercises ${ }^{12}$.

The influence of these $\mathrm{RI}$ on the response following the exercise of neuromuscular, hemodynamic, and biochemical components is very important. However, as exposed, different objectives, and instrumentations are used to evaluate these responses. Thus, the present study aims to conduct a literature review aimed at identifying, and analyzing the objectives, and evaluation methods for the responses after different recovery intervals in resistance training.

\section{Material and method}

This study is in line with the American College of Sports Medicine policies regarding animal, and human experimentation.
The present study is characterized by a systematic review study, being carried out according to the instructions of the Preferred Reporting Items for Systematic Reviews, and Meta-Analysis (PRISMA) statement ${ }^{13}$. Thus, this systematic review adopted the following inclusion criteria: a) studies that investigated the influence of rest intervals in muscle performance; b) studies that presented detailed methodology, sufficient for full understanding of the experimental design; c) Studies that used some instrumentation for muscle performance analysis; (d) articles using the bench press exercise; f) Articles published in English. Articles dated before 2014 were deleted.

Articles found in the following databases were considered for the systematic review: Scopus, PubMed/MEDLINE, Web of Science, Cochrane Library. The following descriptors, and their respective synonyms under the terms MeSH: "Resistance Training", "Rest Interval", and "Bech Press) were used in the databases." As filters were used: a) species (humans), and type of study (original).

These terms have been adjusted for search in each database. The complete search strategy was carried out in four phases. In phase 1 (Identification), publications potentially eligible for review were verified. This phase was from 03 to 7 of September in 2019. In the 2nd phase (Screening) two experient PhD researchers with expertise in systematic review performed the reading of the titles to verify the adequacy to the purpose of this review, and the duplicity of the articles derived from the databases. When a decision could not be made from the readings of the titles, the abstract was used, and, remaining doubt, the reading of the article in full was made. In the 3rd phase of the selection of articles (eligibility) the inclusion, and exclusion criteria established according to the objective proposed in the systematic review, and the verification of the risk of bias were applied to attest to the methodological quality of each study also by experienced researchers in the area of the study. After this phase, the publications that filled out these assumptions moved to the 4th phase (inclusion), thus being included in this review. If necessary, in the items where there was no consensus, the third researcher did the final analysis. All data were entered, and quantified in a data sheet.

\section{Results}

Of the 79 studies found through the search strategy, 72 were excluded, and 7 studies met the inclusion criteria proposed, and were included in the present study. The following flowchart presents the process of selecting articles (Figure 1).

The Table 1 describes the sample participants, and the protocols used in each reviewed study.

The Table 2 presents the objective results, measured variables, and methods used to contemplate the objectives.

\section{Discussion}

After the selection process of articles, seven studies were included, and analyzed in full by this systematic review. These showed comparisons between different times of recovery intervals, and used the straight supine exercise. Of these, four studies included only men, two included men, and women, and one of them did not present this 
Figure 1. Flowchart of selection of articles.

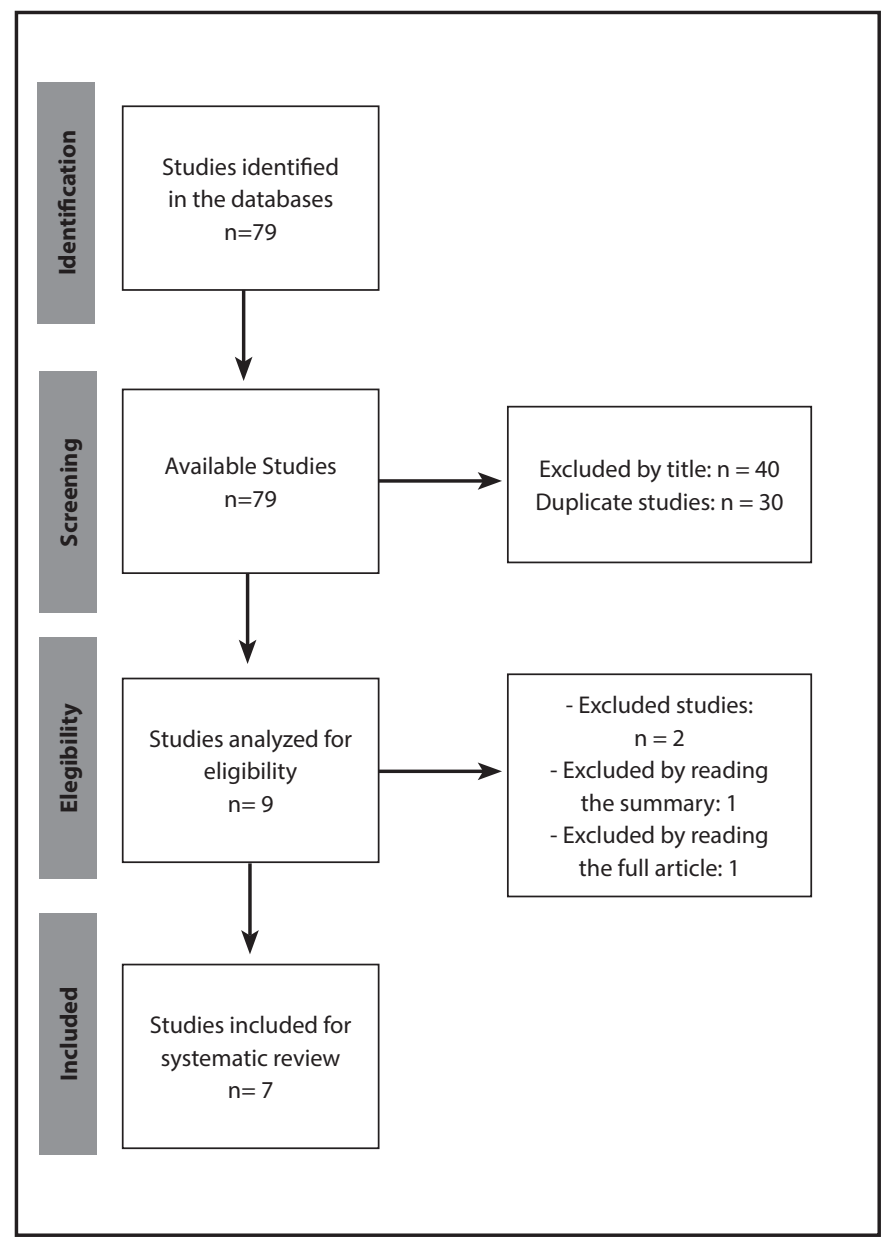

information. Thus, no studies were observed, and there were no women exclusively in their samples. Considering that this population has specific characteristics, such as hormonal ones, for example ${ }^{21}$, the information on the influence of the recovery interval on bodybuilding exercises on biological responses is an important gap in the literature.

In addition, only one investigation observed the influence of different recovery intervals on strength in the elderly. In his study, Villanueva et al. ${ }^{14}$ verified the effect of 1 , and 4 minutes of recovery intervals on body composition, and muscle, and functional performance in 22 elderly men. A 12-week intervention was performed with a program that contained seven strength training exercises, including exercises for upper, and lower limbs. X-ray absorptiometry (DXA) was used to assess body composition. The Star excursion balance, and Margarida power tests checked the performance of the functional control variables of the movement in addition to the 1RM Test to assess muscle strength. The results for this population differ from those performed in young people, when they found that 8 weeks of high-intensity strength TR periodized with short IR induces significantly greater improvements in body composition, muscle performance, and functional performance, compared to the same prescription of RT with higher IR.

From the above, it is understood that for the elderly, a short IR may be sufficient for muscle strength gains. However, for trained young people, most studies have concluded that individuals need a longerterm IR to maximize gains in muscle strength ${ }^{9}$. However, these results are still controversial, as considerable gains in muscle strength can be achieved with a short-term interval. A great example is the study by Bottaro et al. ${ }^{22}$ that verified similar muscle strength gains when comparing short intervals with longer intervals.

To make up the protocols of the studies evaluated in this review, the researchers chose to use percentages of the maximum load, thus making the execution of the exercises at submaximal intensities. Of the

Table 1. Authors, sample, and protocols used.

\begin{tabular}{|c|c|c|}
\hline Author & Sample & Protocol \\
\hline Villanueva et al..$^{14}$ & 22 men & $\begin{array}{l}\text { 2/4 sets/exercise, } 8-15 \text { repetitions of } 7 \text { exercises for } 3 \text { days/week for } 12 \text { weeks } \\
2 \text { RI protocols: } 1 \text { and } 4 \text { minutes }\end{array}$ \\
\hline Fink et al. ${ }^{15}$ & 14 men & $\begin{array}{l}4 \text { sets of bench press followed by } 4 \text { sets of } 40 \% 1 \text { RM squats with } 1 \text { sec in concentric } \\
\text { phases, and } 2 \text { sec in eccentric phases for } 8 \text { weeks } \\
2 \text { RI protocols: } 30 \text { s }(n=7) \text {, and } 150 \mathrm{~s}(n=7)\end{array}$ \\
\hline Davó et al. ${ }^{16}$ & 31 students ( 18 men, and 13 women) & $\begin{array}{l}5 \text { sets of } 8 \text { repetitions on bench press straight with } 40 \% \text { of } 1 \text { RM } \\
3 \text { RI protocols: } 1,2 \text {, and } 3 \text { minutes }\end{array}$ \\
\hline De Salles et al. ${ }^{17}$ & $\begin{array}{l}27 \text { people divided into } 2 \text { groups: } \\
\text { G1 - exercises for lower limbs, and } \\
\text { G2 - exercises for upper limbs. }\end{array}$ & $\begin{array}{l}3 \text { sets with } 75 \% \text { of } 1 \mathrm{RM} \\
2 \text { RI protocols: } 2 \text { min, and self-suggested }\end{array}$ \\
\hline Schoenfeld et al. ${ }^{18}$ & 21 men & $\begin{array}{l}3 \text { sets of } 8 \text { to } 12 \text { RM of } 7 \text { different exercises per session, } 3 \text { times/week for } 8 \text { weeks } \\
2 \text { Rl protocols: } 1 \text { and } 3 \text { minutes. }\end{array}$ \\
\hline Figueiredo et al. ${ }^{19}$ & 11 prehypertensive men & $\begin{array}{l}3 \text { sets of } 8 \text { to } 10 \text { repetitions with } 70 \% \text { of } 1 \mathrm{RM} \\
2 \text { RI protocols: } 1 \text { and } 2 \text { minutes }\end{array}$ \\
\hline Monteiro et al. ${ }^{20}$ & 28 participants: 12 women, and 16 men & $\begin{array}{l}4 \text { sets with } 100 \% 10 \text { RM } \\
4 \text { RI protocols: 1) Bench press followed by Leg Press with } 3 \text { minutes of Rl; } 2 \text { ) Leg Press fo- } \\
\text { llowed by a bench press with } 3 \text { minutes of Rl; } 3 \text { ) Straight bench press followed by leg press } \\
\text { without Rl; 4) Leg Press followed by Straight Bench Press without RI }\end{array}$ \\
\hline
\end{tabular}


Table 2. Objectives, variables, and methods used.

\begin{tabular}{|c|c|c|c|}
\hline Author & Objective & Measured variables & Methods \\
\hline Villanueva et al..$^{14}$ & $\begin{array}{l}\text { Check the effects of RI on body composition, } \\
\text { and muscle performance }\end{array}$ & $\begin{array}{l}\text { 1. Body composition } \\
\text { 2. Functional Performance } \\
\text { 3. Muscle Performance }\end{array}$ & $\begin{array}{l}\text { 1. X-ray absorptiometry (DXA) } \\
\text { 2. Star excursion balance test, Margaria } \\
\text { power test, } 400-\mathrm{m} \text { walk }\end{array}$ \\
\hline Fink et al. ${ }^{15}$ & $\begin{array}{l}\text { Check different RI in acute, and chronic } \\
\text { hormonal responses in hypertrophy, and } \\
\text { strength gains. }\end{array}$ & $\begin{array}{l}\text { 1. GH, T, IGF-1 were verified before } \\
\text { (B), immediately after (P0), } 15 \text { min } \\
\text { after (P15), } 30 \text { min after (P30), and } \\
60 \text { min after (P60) TF sessions. } \\
\text { 2. Total volume of training } \\
\text { performed in the } 4 \text { sets } \\
\text { 3. Muscle cross-sectional area before } \\
\text { the start of the TF program, and in } \\
\text { the last week after the last training } \\
\text { session (week 9) } \\
\text { 4. Muscle strength tests were } \\
\text { performed during the week, } \\
\text { before, and after the training } \\
\text { period. }\end{array}$ & $\begin{array}{l}\text { 1. Precubital Blood Samples } \\
\text { 2. Total number of repetitions } \\
\text { 3. Magnetic resonance } \\
\text { 4. 1RM Test }\end{array}$ \\
\hline Davó et al. ${ }^{16}$ & $\begin{array}{l}\text { To verify the influence of different RI between } \\
\text { the series on the output power performance, } \\
\text { and the physiological, and perceptual variables. }\end{array}$ & $\begin{array}{l}\text { 1. Average power, and peak power } \\
\text { 2. Lactate concentration was co- } \\
\text { llected } 1 \text { minute before, and after } \\
\text { each protocol. } \\
\text { 3. Perceived effort after training } \\
\text { session } \\
\text { 4. Late muscle pain was reported } \\
24 \text {, and } 48 \text { hours after the training } \\
\text { session. }\end{array}$ & $\begin{array}{l}\text { 1. T-Force System } \\
\text { 2. Ear lobe blood samples } \\
\text { 3. Borg Scale (CR-10) } \\
\text { 4. The subjects were asked: "How } \\
\text { painful are the muscles?". Subjective } \\
\text { feeling on a scale of } 0 \text { to } 10 \\
(0=\text { no pain; } 10=\text { much pain })\end{array}$ \\
\hline De Salles et al. ${ }^{17}$ & $\begin{array}{l}\text { Check the effects of fixed RI compared to } \\
\text { self-suggested }\end{array}$ & Exercise Performance & Number of repetitions \\
\hline Schoenfeld et al. ${ }^{18}$ & Check the effects of different RI & $\begin{array}{l}\text { 1. Muscle strength } \\
\text { 2. Muscle endurance } \\
\text { 3. Muscle thickness }\end{array}$ & $\begin{array}{l}\text { 1. } 1 \mathrm{RM} \text { test } \\
\text { 2. } 50 \% \text { from } 1 \mathrm{RM} \text { to failure } \\
\text { 3. Ultrasonography }\end{array}$ \\
\hline Figueiredo et al. ${ }^{19}$ & $\begin{array}{l}\text { To compare the effects of different RI between } \\
\text { sets, and exercises on hemodynamic variables. }\end{array}$ & $\begin{array}{l}\text { 1. Systolic Blood Pressure } \\
\text { 2. Heart Rate }\end{array}$ & $\begin{array}{l}\text { 1. Automatic oscillometric device } \\
\text { 2. Heart Rate Monitor }\end{array}$ \\
\hline Monteiro et al. ${ }^{20}$ & $\begin{array}{l}\text { Check the influence of exercise order, and RI for } \\
\text { an alternating TF sequence of bench press (BP), } \\
\text { and leg press (LP) exercises. }\end{array}$ & $\begin{array}{l}\text { Neuromuscular Fatigue Resistance - } \\
\text { Fatigue Index (FI) }\end{array}$ & $\begin{array}{l}\text { Number of repetitions completed } \\
\text { using the equation proposed by Dipla } \\
\text { et al. (2009) }\end{array}$ \\
\hline
\end{tabular}

seven studies analyzed, two used in their protocols the maximum value of overload verified in the preliminary tests also in their experimental protocols. Just like Villanueva et al. ${ }^{14}$, Fink et al. ${ }^{15}$ also used the 1RM test to assess strength gains. However, Fink et al. ${ }^{15}$ also used blood measurements collected in the antecubital fossa to analyze GH, Testosterone, and IGF-1 levels. Magnetic resonance imaging to evaluate the cross-section area completed the measurements applied by Fink et al. ${ }^{15}$ to compare the effects of 30 , and 150 s of recovery interval between 4 sets to $40 \%$ of 1 RM in 14 men. Load intensity is an important variable for strength training because it influences muscle responses ${ }^{10}$. However, in conclusion, the results of Fink et al. ${ }^{15}$ suggest that acute hormonal responses, as well as chronic changes in hypertrophy, and muscle strength in low load training to failure, are independent of the duration of the rest interval.

Fink et al. ${ }^{15}$, blood measurements also served as a parameter for Davó et al. ${ }^{16}$ evaluate the influence of different recovery intervals in the performance of 5 sets of the supine exercise straight to $40 \%$ of 1 RM in 31 participants. However, unlike Fink et al. ${ }^{15}$, the authors verified lactate levels, coming from blood collections in the earlobe. The T-Force dynamic strength measurement system was used to evaluate muscle strength. The perception of subjective exertion, and late muscle pain were also verified, respectively, through the Borg scale (CR-10), and the specific question "How sore are your muscles". The results suggest that an IR of 2 or 3 minutes is required for mechanical, and physiological recovery, however, there may be little difference between the rest intervals of 2 , and 3 minutes.

Schoenfeld et al. ${ }^{18}$ then used 1 , and 3 minutes of recovery interval for 3 sets of 8-12RM to verify muscle parameters in 21 men. However, the authors differed when using ultrasonography as an instrument. Muscle resistance was also verified through the number of repetitions performed with $50 \%$ of 1 RM up to concentric failure. Schoenfeld et al. ${ }^{18}$ applied the 1RM test to verify muscle strength approaching this time to the study by Fink et al. ${ }^{15}$, and that conducted by Villanueva et al. ${ }^{14}$. Thus, the 1 RM test is widely used in the studies, although in practice it is ineffective because it does not represent the reality of the prescription of ST exercises ${ }^{23}$. 
An alternative to check the accumulated volume of the training is the count of the number of repetitions. This method was used by De Salles et al. ${ }^{17}$ who observed the influence of the recovery interval in 27 men. The study by De Salles et al. ${ }^{17}$ unlike demias, used a different strategy for the recovery interval. It compared the set interval of 2 minutes with the self suggested by the participants. The results showed no significant differences in the number of repetitions between $2 \mathrm{~min}$, and with the self-suggested interval, and that the self-suggested IR group spent on average less time recovering than the group with $I R$ fixed in 2 min. The authors suggest that for trained individuals, the self-suggested method may be an effective option. In addition, the suggested auto IR can reduce the total duration of the training session, which can be an interesting strategy.

Monteiro et al. ${ }^{20}$ also used the number of repetitions to calculate the muscle fatigue index in 28 participants divided into 4 recovery protocols. However, this was the only study verified in this review that aimed to evaluate the influence of different recovery intervals that included both sexes. Twelve women, and 16 men, both trained, performed four sets with $100 \%$ load of $10 \mathrm{RM}$ until the concentric failure in order to complete the maximum number of repetitions with different recovery intervals between the straight supine, and squat exercises.

Figueiredo et al. ${ }^{19}$ were the only researchers found in the present review, who verified the influence of different recovery intervals on hemodynamic variables. 1, and 2 minutes of interval were applied to 3 sets of 8-10 repetitions with 70\% of $1 \mathrm{RM}$. Through an automatic oscillometric device, and a monitor of its own, and specific measurements of heart rate, and blood pressure were obtained. The authors found that 1 or 2 minutes of rest between sets, and exercises can reduce blood pressure after training sessions. However, resting 1 minute between sets, and exercises were associated with increased cardiac stress, and, therefore, this may require the prescription of longer rest intervals between sets, and exercises when working with individuals who have been diagnosed with cardiovascular dysfunction.

\section{Conclusion}

The studies presented verified the effect of different rest intervals on muscle, and hemodynamic responses. Imaging measurements such as ultrasound, and resonance, blood measurements such as $\mathrm{GH}$, Testosterone, IGF-1, and Lactate, repetition numbers for performance, and fatigue, as well as heart rate, and blood pressure were observed.

However, according to this systematic review, articles in the literature need to analyze the association of these measures, demonstrating how these variables behave together. Moreover, neuromuscular behavior is a variable that includes muscle, and neural parameters, reflecting both muscle activation, and the fatigue process, and electromyography is an appropriate instrumentation for this purpose. In addition, time under tension (TUT) is an important variable for the evaluation of the volume, and intensity of the training, which is not verified in any study of the present systematic review.

Given the above, studies that associate muscle, blood, and hemodynamic measurements, as well as those using electromyography as instrumentation, and TUT as a variable, are suggested.

\section{Conflict of interest}

The authors do not declare a conflict of interest.

\section{Bibliography}

1. Medicine ACOS. ACSM's guidelines for exercise testing and prescription. LippincottWilliams \&Wilkins; 2013.

2. Branco BHM, Carvalho IZ, de Oliveira HG, Fanhani AP, dos Santos MCM, de Oliveira LP, et al. Effects of 2 Types of Resistance Training Models on Obese Adolescents' Body Composition, Cardiometabolic Risk, and Physical Fitness. The Journal of Strength \& Conditioning Research. 2019.

3. Fleck SJ, Kraemer WJ. Fundamentos do treinamento de força muscular. Artmed Editora; 2017.

4. HenwoodT. Using evidence in practice: the role of resistance training in avoiding aged care. Journal of Aging and Physical Activity. 2016;24:S96-S.

5. Lacerda LT, Martins-Costa HC, Diniz RC, Lima FV, Andrade AG, Tourino FD, et al. Variations in repetition duration and repetition numbers influence muscular activation and blood lactate response in protocols equalized by time under tension. The Journal of Strength \& Conditioning Research. 2016;30(1):251-8.

6. Simão R, De Salles BF, Figueiredo T, Dias I, Willardson JM. Exercise order in resistance training. Sports Medicine. 2012;42(3):251-65.

7. de Salles BF, Simao R, Miranda F, da Silva Novaes J, Lemos A, Willardson JM. Rest interval between sets in strength training. Sports Medicine. 2009;39(9):765-77.

8. Grgic J, Lazinica B, Mikulic P, Krieger JW, Schoenfeld BJ. The effects of short versus long inter-set rest intervals in resistance training on measures of muscle hypertrophy: $A$ systematic review. European journal of sport science. 2017;17(8):983-93.

9. Grgic J, Schoenfeld BJ, Skrepnik M, Davies TB, Mikulic P. Effects of rest interval duration in resistance training on measures of muscular strength: a systematic review. Sports Medicine. 2018;48(1):137-51.

10. Schoenfeld BJ, Ogborn DI, Krieger JW. Effect of repetition duration during resistance training on muscle hypertrophy: a systematic review and meta-analysis. Sports Medicine. 2015;45(4):577-85.

11. Nogueira DV, Silva SB, de Abreu LC, Valenti VE, Fujimori M, de Mello Monteiro CB, et al. Effect of the rest interval duration between contractions on muscle fatigue. Biomedical engineering online. 2012;11(1):89.

12. Schoenfeld BJ, Ogborn D, Krieger JW. Dose-response relationship between weekly resistance training volume and increases in muscle mass: A systematic review and meta-analysis. Journal of sports sciences. 2017;35(11):1073-82.

13. Liberati A, Altman D, Tetzlaff J, Mulrow C, Gøtzsche P, loannidis J, et al. The PRISMA statement for reporting systematic reviews and meta-analyses of studies that evaluate healthcare interventions. BMJ. 2009;339.

14. Villanueva MG, Lane CJ, Schroeder ET. Short rest interval lengths between sets optimally enhance body composition and performance with 8 weeks of strength resistance training in older men. European journal of applied physiology. 2015;115(2):295-308.

15. Fink JE, Schoenfeld BJ, Kikuchi N, Nakazato K. Acute and long-term responses to different rest intervals in low-load resistance training. International journal of sports medicine. 2017;38(02):118-24.

16. Davó JLH, Solana RS, Marín JMS, Fernández JF, Ramón MM. Rest interval required for power training with power load in the bench press throw exercise. The Journal of Strength \& Conditioning Research. 2016;30(5):1265-74.

17. De Salles BF, Polito MD, Goessler KF, Mannarino P, Matta TT, Simão R. Effects of fixed vs. self-suggested rest between sets in upper and lower body exercises performance. European journal of sport science. 2016;16(8):927-31.

18. Schoenfeld BJ, Pope ZK, Benik FM, Hester GM, Sellers J, Nooner JL, et al. Longer interset rest periods enhance muscle strength and hypertrophy in resistance-trained men. Journal of strength and conditioning research. 2016;30(7):1805-12.

19. Figueiredo T, Willardson JM, Miranda H, Bentes CM, Machado Reis V, Freitas de Salles $B$, et al. Influence of rest interval length between sets on blood pressure and heart rate variability after a strength training session performed by prehypertensive men. Journal of strength and conditioning research. 2016;30(7):1813-24.

20. Monteiro ER, Steele J, Novaes JS, Brown AF, Cavanaugh MT, Vingren JL, et al. Men exhibit greater fatigue resistance than women in alternated bench press and leg press exercises. The Journal of sports medicine and physical fitness. 2019;59(2):238-45.

21. Ribeiro AS, Aguiar AF, Schoenfeld BJ, Nunes JP, Cavalcante EF, Cadore EL, et al. Effects of different resistance training systems on muscular strength and hypertrophy in resistance-trained older women. The Journal of Strength \& Conditioning Research. 2018:32(2):545-53.

22. Bottaro M, Ernesto C, Celes R, Farinatti P, Brown L, Oliveira R. Effects of age and rest interval on strength recovery. International journal of sports medicine. 2010;31(01):22-5.

23. Da Silva JB, LimaVP, De Castro JBP, Paz GA, Novaes JDS, Nunes RDAM, et al. Analysis of myoelectric activity, blood lactate concentration and time under tension in repetitions maximum in the squat exercise. Journal of Physical Education and Sport. 2018;18(4):2478-85. 